\title{
Analysis of energy efficiency of air handling unit with integrated air to air heat exchanger in heating mode
}

\author{
Slav Valchev ${ }^{*}$, and Ivan Mihaylov ${ }^{1}$ \\ ${ }^{1}$ University of Food Technologies, Plovdiv, Bulgaria, Department of Heat Engineering, 26 Maritza \\ Blvd. BG-4002 Plovdiv, Bulgaria
}

\begin{abstract}
Object of the present study is an experimental determination of energy efficiency parameters of air handling unit with integrated air to air heat exchanger: effectiveness of air to air heat exchanger, coefficient of performance and specific fan power of air handling unit. A daily performance of air handling unit is conducted. Effectiveness of supply side of air to air heat exchanger in range of $42.4 \%$ to $52.5 \%$ is received. Coefficient of performance in range of 1.50 to 2.08 and specific fan power of air handling unit in range of $1.39 \mathrm{~kW} /\left(\mathrm{m}^{3} / \mathrm{s}\right)$ to $2.08 \mathrm{~kW} /\left(\mathrm{m}^{3} / \mathrm{s}\right)$ are received. It was found experimentally that effectiveness of air to air heat exchanger depends on values of mass flow of supply and the exhaust air. High values of mass flow of the exhaust air responds to high effectiveness of supply side of air to air heat exchanger.
\end{abstract}

\section{Introduction}

In public buildings to maintain the temperature in rooms a central air handling units are used. The requirements for amount of fresh air in the room impose use of air-to-air heat exchangers with high energy efficiency, who serve to heat (cool) the fresh air supplied to conditioned room. To air handling unit with integrated air to air heat exchanger and heating (cooling) section with direct evaporation of refrigerant energy efficiency is based on the values of three parameters: effectiveness of air to air heat exchanger, coefficient of performance and specific electric fan power, consumed by fans of air handling unit. High values of effectiveness of air to air heat exchanger and coefficient of performance of air handling unit and low values of specific electric fan power of air handling unit indicate high energy efficiency of the system [1].

In this study a relation between effectiveness of supply side of air to air heat exchanger and ratio of heat capacity rates of the supply and exhaust air is received.

\footnotetext{
*Corresponding author: slav_vul4ev@abv.bg
} 


\section{Air handling unit}

For the purpose of the study an air handling unit is built. The installation is located in Plovdiv, Bulgaria, at laboratory of the University Of Food Technology - Plovdiv. Schematic diagram of air handling unit is shown on Figure 1.

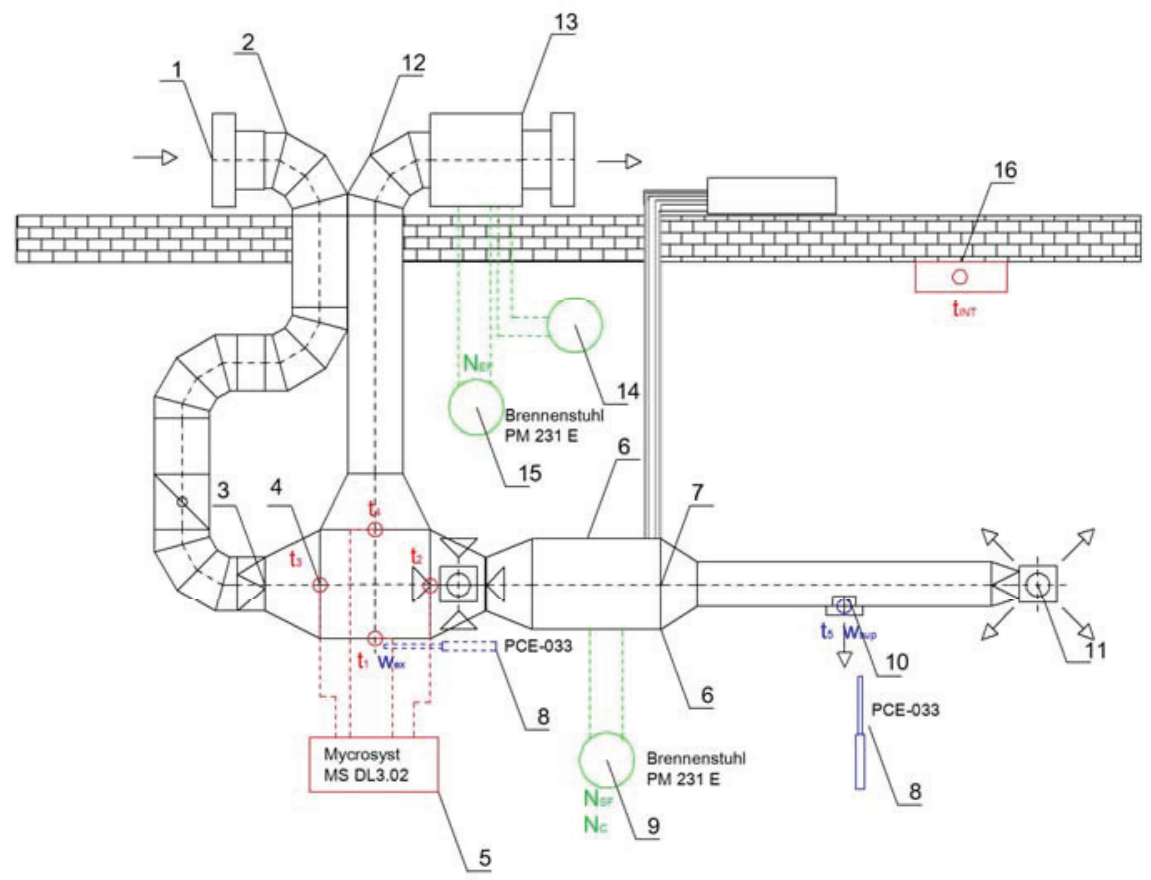

Fig. 1. Schematic diagram of air handling unit

A performance of air handling unit in heating mode is examined. Supply air (100\% fresh air) to an external louver 1 and on supply air duct 2 goes to filter section 3. Supply air is transported to conditioned room by supply fan 7 , mounted in heating section of air handling unit (HP unit) 6. After leaving the filter section 3, supply air enters to air to air plate heat exchanger HE 4, where it is heated by exhaust air from the room. The temperature of supply air on inlet and outlet of HE 4 is measured with temperature sensors, connected to controller 5. Then heated supply air from air to air plate heat exchanger HE 4 goes to HP unit 6 . The temperature of supply air on outlet of HP unit 6 and his velocity are measured by thermo-anemometer 8 . The energy power consumption of HP unit 6 and energy power consumption of supply fan are measured by digital wattmeter 9 . The supply air enters the room from grill on rectangular duct 10 and ceiling grill 11 . The exhaust air is transported on exhaust air duct 12 by exhaust fan 13, mounted in box outside the room. Fan speed of exhaust fan is set by fan speed controller 14. Exhaust air from the room enters to air to air plate heat exchanger HE 4, where it is cooled by supply air from the room. The temperature of exhaust air on inlet and outlet of HE 4 is measured with temperature sensors, connected to controller 5. The velocity of exhaust air on inlet of $\mathrm{HE} 4$ is measured by thermoanemometer 8 . The energy power consumption of exhaust fan are measured by digital wattmeter 15.The temperature of air in the room tint is measured with remote controller 16.

Measuring devices and measured parameters of air handling unit are shown in Table 1. 
Table 1. Measuring devices and measured parameters of air handling unit

\begin{tabular}{|c|c|c|c|c|}
\hline Measuring device & $\begin{array}{l}\text { Measured } \\
\text { parameter }\end{array}$ & Designation & $\begin{array}{l}\text { Precision } \\
\text { measuring }\end{array}$ & $\begin{array}{l}\text { Measuring } \\
\text { range }\end{array}$ \\
\hline $\begin{array}{l}\text { Remote controller Fujitsu } \\
\text { General UTY-RNNYM } 1\end{array}$ & $\begin{array}{l}\text { Set point of room } \\
\text { temperature }\end{array}$ & ${ }^{\mathrm{t}} \mathrm{C}$ & $\pm 1.0^{\circ} \mathrm{C}$ & $10-30{ }^{\circ} \mathrm{C}$ \\
\hline $\begin{array}{l}\text { Controller Mycrosyst } \\
\text { Data Logger GSM Dialer } \\
\text { MS DL3.02 - } 2-4 \text { channel }\end{array}$ & $\begin{array}{l}\text { Air temperatures in } \\
\text { control point of air } \\
\text { handling unit }\end{array}$ & $\stackrel{\mathrm{t}_{1}, \mathrm{t}_{2}, \mathrm{t}_{3}, \mathrm{t}_{4}}{{ }^{\circ} \mathrm{C}}$ & $\pm 0.1^{\circ} \mathrm{C}$ & $10-60^{\circ} \mathrm{C}$ \\
\hline $\begin{array}{l}\text { Thermo-anemometer } \\
\text { PCE-033 }\end{array}$ & $\begin{array}{l}\text { Air temperatures and } \\
\text { velocities in control } \\
\text { point of air handling } \\
\text { unit }\end{array}$ & $\begin{array}{c}\mathrm{t}_{5},{ }^{\circ} \mathrm{C} \\
\mathrm{w}_{\text {sup }}, \mathrm{W}_{\mathrm{ex}} \\
\mathrm{m} / \mathrm{s}\end{array}$ & $\begin{array}{c}\text { Temperature: } \\
\pm 0.1^{\circ} \mathrm{C} \\
\text { Velocity: } \\
\pm 0.1 \mathrm{~m} / \mathrm{s}\end{array}$ & $\begin{array}{c}\text { Temperature: } \\
0.0-50{ }^{\circ} \mathrm{C} \\
\text { Velocity: } \\
0.2-20 \mathrm{~m} / \mathrm{s}\end{array}$ \\
\hline $\begin{array}{l}\text { Digital wattmeter } \\
\text { Brennenstuhl PM } 231 \text { E }\end{array}$ & $\begin{array}{l}\text { Current power } \\
\text { consumption of } \\
\text { electrical energy spent } \\
\text { by refrigeration } \\
\text { compressor and } \\
\text { supply air fan; }\end{array}$ & $\begin{array}{c}\mathrm{N}_{\mathrm{SF}}, \mathrm{N}_{\mathrm{C}} \\
\mathrm{W}\end{array}$ & $\pm 0.2 \mathrm{~W}$ & $\begin{array}{c}0-9999.9 \\
\text { kWh }\end{array}$ \\
\hline $\begin{array}{l}\text { Digital wattmeter } \\
\text { Brennenstuhl PM } 231 \mathrm{E}\end{array}$ & $\begin{array}{c}\text { Current power } \\
\text { consumption of } \\
\text { electrical energy spent } \\
\text { by exhaust air fan }\end{array}$ & $\begin{array}{c}\mathrm{N}_{\mathrm{EF}}, \\
\mathrm{W}\end{array}$ & $\pm 0.2 \mathrm{~W}$ & $\begin{array}{c}\text { 0-9999.9 } \\
\text { kWh }\end{array}$ \\
\hline
\end{tabular}

General appearance of air handling unit are shown in Figure 2.

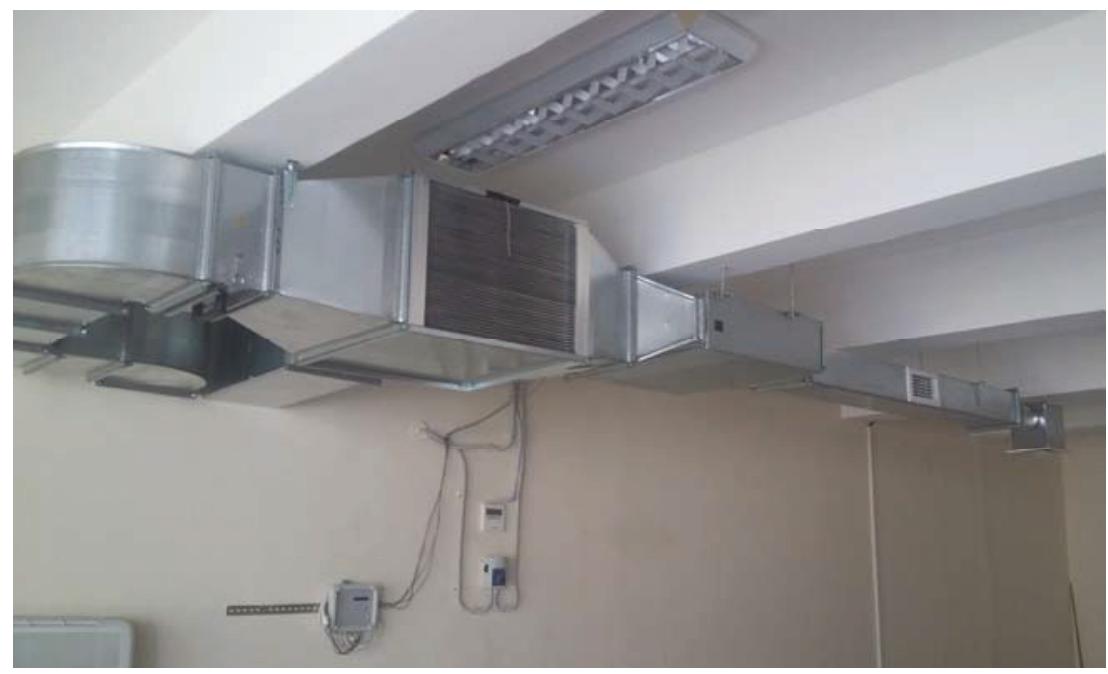

Fig. 2. General appearance of air handling unit [2] 


\section{Analysis and discussion}

\subsection{Basic equation}

The mass flow rates of supply air and exhaust air through heat exchanger are determined by equations:

$$
\begin{aligned}
& m_{\text {sup }}=\rho_{\text {air }} \cdot w_{\text {sup }} \cdot f_{\text {sup }}, \\
& m_{e x}=\rho_{\text {air }} \cdot w_{e x} \cdot f_{e x},
\end{aligned}
$$

where: - $\rho_{\text {air }}$ - density of air for average temperature of air on inlet and outlet of air to airheat exchanger, $\mathrm{kg} / \mathrm{m}^{3}$;

$\mathrm{W}_{\text {sup }}$ - velocity of supply air on outlet of grill of rectangular duct, $\mathrm{m} / \mathrm{s}$;

$\mathrm{W}_{\mathrm{ex}}$ - velocity of exhaust air on inlet of air to air heat exchanger, $\mathrm{m} / \mathrm{s}$;

$\mathrm{f}_{\text {sup }}$ - effective area of grill on rectangular duct, $\mathrm{m}^{2}$.

$\mathrm{f}_{\mathrm{ex}}$ - effective area of ait to air heat exchanger, $\mathrm{m}^{2}$.

Heat capacity rate of the supply air and exhaust air can be calculated with the following equations:

$$
\begin{gathered}
C_{s}=\dot{m_{\text {sup }}} \cdot C_{\text {air }}, \\
C_{e}=\dot{m}_{e x} \cdot C_{a i r},
\end{gathered}
$$

where: - $m_{\text {sup }}-$ mass flow rate of supply air through the heat exchanger, $\mathrm{kg} / \mathrm{s}$;

$m_{e x}$ - mass flow rate of exhaust air through the heat exchanger, $\mathrm{kg} / \mathrm{s}$;

$\mathrm{C}_{\text {air }}$ - specific heat capacity of air, $\mathrm{kJ} / \mathrm{kg} . \mathrm{K},\left(\mathrm{C}_{\text {air }}=1,0 \mathrm{~kJ} / \mathrm{kg} \cdot \mathrm{K}\right)$.

Effectiveness on a supply side of air to air heat exchanger $\varepsilon_{\mathrm{s}}$ is determined as follows:

$$
\varepsilon_{s}=\frac{C_{s}}{C_{\min }} \cdot\left(\frac{t_{2}-t_{3}}{t_{1}-t_{3}}\right) \cdot 100,
$$

where: $-\mathrm{C}_{\min }-$ minimum of $\mathrm{C}_{\mathrm{s}}$ and $\mathrm{C}_{\mathrm{e}}, \mathrm{kW} / \mathrm{K}$.

$\mathrm{t}_{2}$ - temperature of supply air on outlet of air to air heat exchanger, ${ }^{\circ} \mathrm{C}$;

$\mathrm{t}_{3}$ - temperature of supply air on inlet of air to air heat exchanger, ${ }^{\circ} \mathrm{C}$;

$\mathrm{t}_{1}-$ temperature of exhaust air on inlet of air to air heat exchanger, ${ }^{\circ} \mathrm{C}$.

$\mathrm{t}_{4}$ - temperature of exhaust air on outlet of air to air heat exchanger, ${ }^{\circ} \mathrm{C}$.

Heat flux exchanged in the heating section (HP unit) is determined by equation of energy balance of air flow rate through heating section [5]:

$$
Q_{H P}=\dot{m}_{\text {sup }} \cdot C_{\text {air }}\left(t_{5}-t_{2}\right)
$$

where: - $\mathrm{t}_{5}$ - temperature of supply air on outlet of heating section (HP unit), ${ }^{\circ} \mathrm{C}$;

Heat flux exchanged in air to air heat exchanger is determined by the equation of energy balance of air flow rate through air to air heat exchanger:

$$
Q_{H E}=m_{\text {sup }} \cdot C_{\text {air }}\left(t_{2}-t_{3}\right)
$$

Total heating capacity of air handling unit is calculated as: 


$$
\dot{Q}_{A H U}=\dot{Q}_{H P}+\dot{Q}_{H E}
$$
8]:

Coefficient of performance of heating section (HP unit) is calculated by equation $[6,7$,

$$
C O P_{H P}=\frac{Q_{H P}}{\left|N_{C}\right|},
$$

where:- $\mathrm{N}_{\mathrm{C}}$ - electrical power for refrigeration compressor of heat pump unit, $\mathrm{W}$.

Total power consumption of supply and exhaust fan of air handling unit is calculated as:

$$
N_{F}=N_{S F}+N_{E F},
$$

where: - NSF - electrical power for supply fan of air handling unit, W;

$\mathrm{N}_{\mathrm{EF}}$ - electrical power for exhaust fan of air handling unit, W.

Total power consumption of air handling unit is determined by equation:

$$
N_{\text {TOT }}=N_{C}+N_{S F}+N_{E F}
$$

Coefficient of performance of air handling unit is calculated by equation:

$$
C O P_{A H U}=\frac{Q_{A H U}}{\left|N_{T O T}\right|}
$$

Specific fan power of air handling unit SFP is determined as follows:

$$
S F P=\frac{N_{F} \cdot \rho_{a i r}}{m_{M A X}},
$$

where:- $m_{M A X}=m_{e x}-$ maximum mass flow rate throw air to air heat exchanger, equal to mass flow rate of exhaust air throw air to air heat exchanger, $\mathrm{kg} / \mathrm{s}$.

Volume flow rate of exhaust air can be calculated by following equation:

$$
\dot{V}_{e x}=\frac{m_{e x}}{\rho_{\text {air }}}
$$

\subsection{Results}

A daily performance of air handling unit is conducted. The temperatures of supply air on outlet $\mathrm{t}_{2}$ and inlet $\mathrm{t}_{3}$ of air to air heat exchanger and temperature of exhaust air on inlet $\mathrm{t}_{1}$ of air to air heat exchanger are measured three times for one hour. The velocities of supply air $\mathrm{W}_{\text {sup }}$ and exhaust air $\mathrm{W}_{\mathrm{ex}}$ of air handling unit are measured three times for one hour. Respective arithmetical mean values of measured temperatures and velocities are calculated. Mass flow rates of supply air and exhaust air through heat exchanger are determined by equations (1), (2). The results are shown in Table 2 .

Heat capacity rate of the supply air $\mathrm{C}_{s}$ and heat capacity rate of the exhaust air $\mathrm{C}_{\mathrm{e}}$ are determined by equations (3), (4). Effectiveness on a supply side of air to air heat exchanger $\varepsilon_{\mathrm{s}}$ is determined by equation (5). The results are shown in Table 3 . 
Table 2. Experimental data - Temperatures and mass flow rates heat exchanger

\begin{tabular}{|c|c|c|c|c|c|c|c|c|}
\hline \multirow{2}{*}{$№$} & $\mathrm{t}_{1}$ & $\mathrm{t}_{2}$ & $\mathrm{t}_{3}$ & $\mathrm{t}_{4}$ & $\mathrm{w}_{\text {sup }}$ & $\dot{m}_{\text {sup }}$ & $\mathrm{w}_{\mathrm{ex}}$ & $\dot{m}_{\text {ex }}$ \\
\cline { 2 - 9 } & ${ }^{\circ} \mathrm{C}$ & ${ }^{\circ} \mathrm{C}$ & ${ }^{\circ} \mathrm{C}$ & ${ }^{\circ} \mathrm{C}$ & $\mathrm{m} / \mathrm{s}$ & $\mathrm{kg} / \mathrm{s}$ & $\mathrm{m} / \mathrm{s}$ & $\mathrm{kg} / \mathrm{s}$ \\
\hline 1 & 15.0 & 10.1 & 6.5 & 11.5 & 5.9 & 0.0889 & 0.7 & 0.1036 \\
\hline 2 & 15.2 & 10.4 & 6.8 & 12.0 & 5.8 & 0.0871 & 0.7 & 0.1033 \\
\hline 3 & 17.3 & 12.3 & 7.4 & 14.0 & 5.6 & 0.0838 & 0.8 & 0.1172 \\
\hline 4 & 18.4 & 14.0 & 9.3 & 15.5 & 5.3 & 0.0787 & 0.8 & 0.1168 \\
\hline 5 & 21.3 & 15.9 & 10.2 & 17.8 & 5.3 & 0.0785 & 0.8 & 0.1156 \\
\hline 6 & 22.6 & 16.9 & 10.6 & 19.2 & 5.2 & 0.0767 & 0.8 & 0.1152 \\
\hline 7 & 24.6 & 17.9 & 10.9 & 21.3 & 5.0 & 0.0738 & 0.9 & 0.1287 \\
\hline 8 & 25.1 & 17.3 & 9.1 & 21.9 & 4.6 & 0.0679 & 1.0 & 0.1425 \\
\hline 9 & 25.2 & 17.0 & 8.2 & 22.2 & 4.3 & 0.0637 & 1.0 & 0.1425 \\
\hline 10 & 24.8 & 16.5 & 7.9 & 21.8 & 4.2 & 0.0622 & 1.0 & 0.1430 \\
\hline
\end{tabular}

Table 3. Experimental data - Effectiveness supply side heat exchanger

\begin{tabular}{|c|c|c|c|c|c|c|}
\hline \multirow{2}{*}{ № } & $\dot{m}_{\text {sup }}$ & $\dot{m}_{\text {ex }}$ & $\mathrm{C}_{\mathrm{s}}$ & $\mathrm{C}_{\mathrm{e}}$ & $\mathrm{C}_{\mathrm{s}} \mathrm{C}_{\mathrm{e}}$ & $\varepsilon_{\mathrm{s}}$ \\
\cline { 2 - 7 } & $\mathrm{kg} / \mathrm{s}$ & $\mathrm{kg} / \mathrm{s}$ & $\mathrm{kW} / \mathrm{K}$ & $\mathrm{kW} / \mathrm{K}$ & - & $\%$ \\
\hline 1 & 0.0889 & 0.1036 & 0.0889 & 0.1036 & 0.86 & 42.4 \\
\hline 2 & 0.0871 & 0.1033 & 0.0871 & 0.1033 & 0.84 & 42.9 \\
\hline 3 & 0.0838 & 0.1172 & 0.0838 & 0.1172 & 0.71 & 49.5 \\
\hline 4 & 0.0787 & 0.1168 & 0.0787 & 0.1168 & 0.67 & 51.6 \\
\hline 5 & 0.0785 & 0.1156 & 0.0785 & 0.1156 & 0.68 & 51.4 \\
\hline 6 & 0.0767 & 0.1152 & 0.0767 & 0.1152 & 0.67 & 52.5 \\
\hline 7 & 0.0738 & 0.1287 & 0.0738 & 0.1287 & 0.57 & 51.1 \\
\hline 8 & 0.0679 & 0.1425 & 0.0679 & 0.1425 & 0.48 & 51.3 \\
\hline 9 & 0.0637 & 0.1425 & 0.0637 & 0.1425 & 0.45 & 51.8 \\
\hline 10 & 0.0622 & 0.1430 & 0.0622 & 0.1430 & 0.43 & 50.9 \\
\hline
\end{tabular}

Heat flux exchanged in heat pump unit $Q_{H P}$ and coefficient of performance in the heating section (heat pump unit) $\mathrm{COP}_{\mathrm{HP}}$ are calculated by equations (6), (9). Electrical power of refrigeration compressor $\mathrm{N}_{\mathrm{C}}$ is measured three times in one hour and respective arithmetical mean values of this power are calculated. The results are shown in Table 4.

Heat flux exchanged in air to air heat exchanger $Q_{H E}$ and total heat capacity of air handling unit $Q_{A H U}$ are calculated by the equations (7), (8). Coefficient of performance of air handling unit $\mathrm{COP}_{\mathrm{AHU}}$ is calculated by equation (12). Power consumption of supply $\mathrm{N}_{\mathrm{SF}}$ and exhaust fan of $\mathrm{N}_{\mathrm{EF}}$ of air handling unit is measured three times in one hour and respective arithmetical mean values of this power are calculated. Total power consumption of air handling unit $\mathrm{N}_{\text {TOT }}$ is calculated by equation (11). The results are shown in Table 5 .

Specific fan power of air handling unit SFP is determined by equation (15). Volume flow rate of exhaust air is calculated by equation (16). Total power consumption of supply and exhaust fan of air handling unit $\mathrm{N}_{\mathrm{F}}$ is calculated by equation (10). The results are shown in Table 6. 
Table 4. Experimental data - Coefficient of performance on heat pump unit

\begin{tabular}{|c|c|c|c|c|c|c|c|}
\hline \multirow{2}{*}{ № } & $\mathrm{t}_{2}$ & $\mathrm{t}_{5}$ & $\mathrm{w}_{\text {sup }}$ & $\dot{m}_{\text {sup }}$ & $Q_{H P}$ & $\mathrm{~N}_{\mathrm{C}}$ & COP $_{\mathrm{HP}}$ \\
\cline { 2 - 8 } & ${ }^{\circ} \mathrm{C}$ & ${ }^{\circ} \mathrm{C}$ & $\mathrm{m} / \mathrm{s}$ & $\mathrm{kg} / \mathrm{s}$ & $\mathrm{W}$ & $\mathrm{W}$ & - \\
\hline 1 & 10.1 & 26.8 & 5.9 & 0.0889 & 1485 & 987.7 & 1.50 \\
\hline 2 & 10.4 & 27.7 & 5.8 & 0.0871 & 1506 & 996.3 & 1.51 \\
\hline 3 & 12.3 & 31.6 & 5.6 & 0.0838 & 1617 & 1114.4 & 1.45 \\
\hline 4 & 14.0 & 33.5 & 5.3 & 0.0787 & 1535 & 1100.8 & 1.39 \\
\hline 5 & 15.9 & 36.8 & 5.3 & 0.0785 & 1640 & 994.6 & 1.65 \\
\hline 6 & 16.9 & 40.9 & 5.2 & 0.0767 & 1841 & 990.9 & 1.86 \\
\hline 7 & 17.9 & 41.4 & 5.0 & 0.0738 & 1733 & 991.6 & 1.75 \\
\hline 8 & 17.3 & 43.8 & 4.6 & 0.0679 & 1798 & 954.0 & 1.88 \\
\hline 9 & 17.0 & 43.2 & 4.3 & 0.0637 & 1668 & 935.6 & 1.78 \\
\hline 10 & 16.5 & 41.0 & 4.2 & 0.0622 & 1523 & 948.6 & 1.61 \\
\hline
\end{tabular}

Table 5. Experimental data - Coefficient of performance of air handing unit

\begin{tabular}{|c|c|c|c|c|c|c|c|}
\hline \multirow{2}{*}{ № } & $\mathrm{t}_{2}$ & $\mathrm{t}_{3}$ & $\dot{m}_{\text {sup }}$ & $\dot{Q}_{\text {HE }}$ & $\dot{Q}_{\text {AHU }}$ & $\mathrm{N}_{\text {TOT }}$ & $\mathrm{COP}_{\text {AHU }}$ \\
\cline { 2 - 8 } & ${ }^{\circ} \mathrm{C}$ & ${ }^{\circ} \mathrm{C}$ & $\mathrm{kg} / \mathrm{s}$ & $\mathrm{W}$ & $\mathrm{W}$ & $\mathrm{W}$ & - \\
\hline 1 & 10.1 & 6.5 & 0.0889 & 320 & 1805 & 1157.7 & 1.56 \\
\hline 2 & 10.4 & 6.8 & 0.0871 & 313 & 1820 & 1171.3 & 1.55 \\
\hline 3 & 12.3 & 7.4 & 0.0838 & 410 & 2027 & 1287.4 & 1.57 \\
\hline 4 & 14.0 & 9.3 & 0.0787 & 370 & 1905 & 1272.8 & 1.50 \\
\hline 5 & 15.9 & 10.2 & 0.0785 & 447 & 2087 & 1168.6 & 1.79 \\
\hline 6 & 16.9 & 10.6 & 0.0767 & 483 & 2324 & 1161.9 & 2.00 \\
\hline 7 & 17.9 & 10.9 & 0.0738 & 516 & 2250 & 1163.6 & 1.93 \\
\hline 8 & 17.3 & 9.1 & 0.0679 & 557 & 2355 & 1130.0 & 2.08 \\
\hline 9 & 17.0 & 8.2 & 0.0637 & 560 & 2228 & 1103.6 & 2.02 \\
\hline 10 & 16.5 & 7.9 & 0.0622 & 535 & 2058 & 1115.6 & 1.84 \\
\hline
\end{tabular}

Table 6. Experimental data - Specific fan power of air handling unit

\begin{tabular}{|c|c|c|c|c|c|c|c|}
\hline № & $\dot{m_{e x}}$ & $V_{e x}$ & $\mathrm{~N}_{\mathrm{SF}}$ & $\mathrm{N}_{\mathrm{EF}}$ & $\mathrm{N}_{\mathrm{C}}$ & $\mathrm{N}_{\mathrm{TOT}}$ & SFP \\
\cline { 2 - 8 } & $\mathrm{kg} / \mathrm{s}$ & $\mathrm{m}^{3} / \mathrm{s}$ & $\mathrm{W}$ & $\mathrm{W}$ & $\mathrm{W}$ & $\mathrm{W}$ & $\mathrm{kW} /\left(\mathrm{m}^{3} / \mathrm{s}\right)$ \\
\hline 1 & 0.1036 & 0.0840 & 18.0 & 152.0 & 987.7 & 1157.7 & 2.02 \\
\hline 2 & 0.1033 & 0.0840 & 20.0 & 155.0 & 996.3 & 1171.3 & 2.08 \\
\hline 3 & 0.1172 & 0.0960 & 23.0 & 150.0 & 1114.4 & 1287.4 & 1.80 \\
\hline 4 & 0.1168 & 0.0960 & 22.0 & 150.0 & 1100.8 & 1272.8 & 1.79 \\
\hline 5 & 0.1156 & 0.0960 & 21.0 & 153.0 & 994.6 & 1168.6 & 1.81 \\
\hline 6 & 0.1152 & 0.0960 & 20.0 & 151.0 & 990.9 & 1161.9 & 1.78 \\
\hline 7 & 0.1287 & 0.1080 & 19.0 & 153.0 & 991.6 & 1163.6 & 1.59 \\
\hline 8 & 0.1425 & 0.1200 & 23.0 & 153.0 & 954.0 & 1130.0 & 1.47 \\
\hline 9 & 0.1425 & 0.1200 & 20.0 & 148.0 & 935.6 & 1103.6 & 1.40 \\
\hline 10 & 0.1430 & 0.1200 & 22.0 & 145.0 & 948.6 & 1115.6 & 1.39 \\
\hline
\end{tabular}


In Figure 3 a correlation between effectiveness of supply side of air to air heat exchanger and ratio of heat capacity rates of supply and exhaust air is shown.

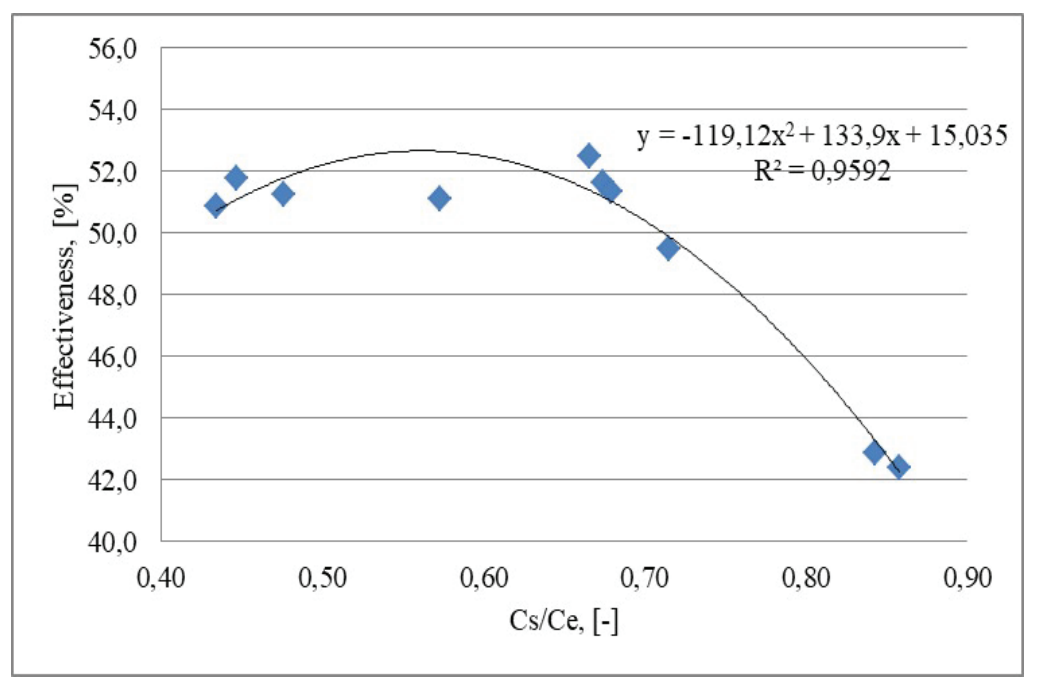

Fig. 3. Correlation between effectiveness of supply side of air to air heat exchanger and ratio of heat capacity rates of supply and exhaust air

\section{Conclusions}

A daily performance of air handling unit is conducted. Experimentally determined values of effectiveness of supply side of air to air heat exchanger in range of $42.4 \%$ to $52.5 \%$ are received. Coefficient of performance of air handling unit in range of 1.50 to 2.08 and specific fan power of air handling unit in range of $1.39 \mathrm{~kW} /(\mathrm{m} 3 / \mathrm{s})$ to $2.08 \mathrm{~kW} /\left(\mathrm{m}^{3} / \mathrm{s}\right)$ are received. It was found experimentally that effectiveness of supply side of air to air heat exchanger depends on values of mass flow of supply and the exhaust air. High values of mass flow of the exhaust air responds to high effectiveness of supply side of air to air heat exchanger.

\section{References}

1. V. Bobilov, G. Genchev, P.Mushakov, P. Zlatev, Z. Kolev. Proc. of Univ. of Ruse Bulgaria, 50 (1.2), 8-12 (2011)

2. S. Valchev, M.Minchev, M.Arnaudov, Sc. Works Un. of Sc. Bulg. - Plovdiv, XVII (C), 14-17 (2019)

3. K. Larson, F. Pihlquist. Methods of Increasing Thermal Efficiency of a Counter Flow Air to Air Heat Exchanger. (Master of Science Thesis, Chalmers University of Technology, Göteborg, Sweden, 2011)

4. V. Pisarev, S. Rabczak, K. Nowak. J. Ecol Eng.,17(5),163-172, (2016)

5. Masitah, A.R.S., M. I Ahmad and Y.M. Yatim. Energy Res.earch J., 6(1), 7-14 (2015)

6. G. Zhou, Y. Ye, W. Zuo, J. Wang. Appl. Therm. Eng. 143, 137-148 (2018)

7. S. Gendebien, J. Martens, L. Prieels, V. Lemort. Build. Simul.:11(3), (2017)

8. S. Dichev, Refrigeration machines. (In Bulgarian - Academic Publishing of VIHVP Plovdiv, 2002) 